\title{
Seroprevalence of HCMV among Pregnant Women and Its relation to $\mathrm{CD} 4$ and $\mathrm{CRP}$
}

\author{
Staar Mohammed Qader \\ Medical Laboratory Department \\ Dibis Sector for Primary Health Care \\ Kirkuk Health Directorate \\ Kirkuk, Iraq \\ stardupiz@gmail.com
}

\begin{abstract}
The HCMV is a widespread viral pathogen characterized by strict host specificity and is limited to humans. It has been described as an important etiological agent of intrauterine infection in during the pregnancy, which may lead to some serious results such as miscarriage, cerebellar malformation stillbirth, and fetus developmental retardation. The study carried out in Kirkuk governorate from the December 2017 to May 2018 for study the relation of CD4 percentage and CRP with HCMV seropositive pregnant women. The number of pregnant women under study was two hundred women attending to some private medical laboratories in Kirkuk. The pregnant women were examined for the seroprevalence of HCMV IgM and IgG antibodies by using VIDAS technique. The results were (81\%), (9\%) and (6\%) for HCMV-IgG, HCMV-IgM and for both IgG \& IgM at the same time respectively. The highest rates (41.66\%) of decreased CD4 percentage were within seropositive pregnant women for both $\mathrm{IgG} \& \mathrm{IgM}$ at same time, while the highest rates (16.66\%)of CRP positive were found within $\mathrm{HCMV}$-IgM seropositive group.
\end{abstract}

Keywords: HCMV, CRP, CD4, VIDAS Pregnant Women.

\section{INTRODUCTION}

Human Cytomegalovirus (HCMV) is an enveloped DNA virus and a member of the herpes family and beta herpes subfamily [1]. The double-stranded DNA genome is composed of 240 kilo base that code for more than 100 proteins [2]. The virus consists of a $64 \mathrm{~nm}$ core which enclosed by a $110 \mathrm{~nm}$ icosahedral capsid consist of 162 capsomeres. A lipid bilayer envelope which surrounds a poorly defined tegument that, in turn, surrounds the viral capsid. The diameter of mature, enveloped viral particle is about 200nm [3]. The HCMV consider as a commonest viral infection during pregnancy, and as a major cause of intrauterine and congenital infection. The most consequence of a primary infection during pregnancy, affecting newborns including; hearing loss, mental retardation, and motor and cognitive impairment [4-7].

The natural HCMV infection is complex and characterized by lifelong latency punctuated by episodes of recurrent infection following the primary infection [8]. The effect for the fetus is even high and more serious when the mother has recently had infected and has not developed any specific HCMV antibodies [9].

The cellular immune response against HCMV by different components that originate from both the adaptive and innate immune systems. The importance of the functional capacity of the HCMV-specific T cells in response to the virus directly (CD8+ and $\mathrm{CD} 4+\mathrm{T}$ cells) lies in demonstrating the extreme complexity and breadth of the $\mathrm{T}$ cell responses that are elicited by the human host response to natural infection [10-12].

The CD4 molecule is a $62 \mathrm{kDa}$ glycoprotein that is found on approximately $60 \%$ of peripheral blood $\mathrm{T}$ lymphocytes and a variable percentage of monocytes. The CD4 molecule is responsible for the recognition of type II major histocompatibility antigens (MHC-II). The CD4T cells function primarily as a helper or promoter of immune functions through $\mathrm{T}$ cell-T cell, $\mathrm{T}$ cell-B cell and $T$ cell-macrophage interactions, that have an essential role in regulation the immune response [13]. The CD4 T cells are important in the induction and regulation of the cellular immune response to pathogens during infection, and an impaired HCMV-specific CD4 T cell immune response has been correlated to the prolonged viral secretion[14]. There is increasing data which emphasizes a significant role for $\mathrm{CD} 4 \mathrm{~T}$ cell responses in the control of infection and these cells are likely to be important in aiding control of HCMV [15,16].

The CD4 cell, a subset of T lymphocyte, is the most important immune cell of the body to regulate human's immune system. It's consider as a commander of all immune cells, provides help and guidance to other cells, thus enabling normal operations of immune system, therefore it is called "Commander in Chief" of immune system [17]. The C-Reactive Protein (CRP) consider as a significant component of the innate immune system, acts as an opsonin and activates the classical complement pathway [18]. The CRP reflects a measure of the acute phase response that plays a protective role against active bacterial and viral infections and also been found to be moderately elevated in the during herpesvirus infections [19-23]. It is synthesized by hepatocytes in response to factors released by adipocytes and is classified as an acute phase protein on the basis of elevated plasma concentration during the infection [24]. 


\section{METHODS AND MATERIALS}

A cross sectional study was carried out at Kirkuk governorate from July 2017 to January 2018 for studying the seroprevalence of HCMV among pregnant women and its relation to CD4 and CRP in 200 pregnant women whose age ranges between 18-42 years, attending some private medical laboratories. Seven and half $\mathrm{ml}$ of blood was collected by vein puncture using $10 \mathrm{ml}$ disposable syringe from each woman enrolled in this study. Blood samples were placed into two sterile test tubes, in one of them 2.5 $\mathrm{ml}$ of blood was put in test tube containing anticoagulant EDTA and lymphocyte isolated by ficoll solution(FicollPaque PLUS ,From GE Healthcare BioSciences-Sweden) and putted in clear test tube labeled for CD4 study by fluorescent microscope using CD4:FITC, (from AbDSero Tec-MorphoSys United Kingdom) .The second part of sample was $5 \mathrm{ml}$ placed in plane tubes left for 30 minutes at $37^{\circ} \mathrm{C}$ then were centrifuged at $3000 \mathrm{rpm}$ for 15 minutes then the clot removed and re-centrifuged the remain for 10 minutes twice time and the obtained sera aspirated and transferred into clean test tube. Label was fixed on each test tube which then stored in deep freeze at $-20^{\circ} \mathrm{C}$ for late serological testing for detecting specific HCMV-IgM and HCMV-IgG by using; VIDAS technique, and for CRP test by latex agglutination test. A computerized statistically analysis was performed using Statistical Package for Science Services(SPSS)version 17, Inc. USA. The comparison was carried out using of Chisquare $\left(\mathrm{X}^{2}\right)$ and Probability value $(\mathrm{P})$. The $\mathrm{P} \leq 0.05$ was categorized as statistically significant $(\mathrm{S})$, and less than 0.01 was considered as highly significant (H.S.) and greater than 0.05 was considered as non-significant(N.S.).

\section{RESULTS}

A total 200 pregnant women were examined for the seroprevalence of HCMV antibodies (HCMV- IgG and HCMV-IgM) by using VIDAS techniques. The seroprevalence of HCMV- IgG, HCMV- IgM and both HCMV- IgG /IgM seropositive at the same time were; 162 $(81.00 \%), 18(9.00 \%)$ and $12(6.00 \%)$ respectively, while the rates among 110 control (non-pregnant women) were $24(21.81 \%), 3(2.72 \%)$ and $2(1.81 \%)$ respectively as shows in (Table 1$)$.

Table (4) shows the relation of CRP with seroprevalence of HCMV antibodies during the pregnancy, so the rates of seronegative HCMV (pregnant women) and 81 time respectively. While increased CD4 percentage seen only in one HCMV- IgG seropositive pregnant woman.

Table (3) shows the CD4 percentage in control groups; 8 HCMV seronegative (pregnant women) and 81 time respectively. positive results of CRP test were $7.40 \%, 19.66 \%$ and $8.33 \%$ among HCMV-IgG, HCMV- IgM and both HCMV- IgG /IgM at the same time seropositive respectively. Regarding to the Correlation of HCMV antibodies with CD4 percentage and CRP test, the highest rate of positive CRP was seen among pregnant with HCMV seropositive with decreased the level of peripheral CD4\% as shown in table 5 .

Table 1: Seroprevalence of HCMV antibodies among pregnant women and control.

\begin{tabular}{|c|c|c|c|c|}
\hline \multirow{3}{*}{$\begin{array}{c}\text { Seroprevalence } \\
\text { of HCMV } \\
\text { antibodies }\end{array}$} & \multicolumn{4}{|c|}{$\begin{array}{c}\text { Seroprevalence of HCMV } \\
\text { antibodies }\end{array}$} \\
\hline & \multicolumn{2}{|c|}{$\begin{array}{l}\text { Pregnant } \\
\text { women }\end{array}$} & \multicolumn{2}{|c|}{$\begin{array}{l}\text { Control group } \\
\text { (Non-pregnant } \\
\text { married women) }\end{array}$} \\
\hline & No. & $\%$ & No. & $\%$ \\
\hline IgM (-) and IgG (+) & 162 & 81.0 & 24 & 21.82 \\
\hline IgM (+) and IgG (-) & 18 & 9.0 & 3 & 2.73 \\
\hline IgM (+) and IgG (+) & 12 & 6.0 & 2 & 1.81 \\
\hline IgM (-) and IgG (-) & 8 & 4.0 & 81 & 73.64 \\
\hline Total & 200 & 100 & 110 & 100 \\
\hline$X^{2}=168.166$ & & $>0$. & & \\
\hline
\end{tabular}

Table 2: Relation of HCMV antibodies with CD4 Percentage.

\begin{tabular}{|c|c|c|c|c|c|c|}
\hline \multirow{3}{*}{$\begin{array}{c}\text { CD4 } \\
\text { percentage }\end{array}$} & \multicolumn{6}{|c|}{ Seropositive of HCMV antibodies } \\
\hline & \multicolumn{2}{|c|}{ HCMV- IgG } & \multicolumn{2}{|c|}{$\begin{array}{c}\text { HCMV- } \\
\text { IgM }\end{array}$} & \multicolumn{2}{|c|}{$\begin{array}{l}\text { HCMV (IgG } \\
\& \text { IgM) }\end{array}$} \\
\hline & No. & $\%$ & No & $\%$ & No & $\%$ \\
\hline $\begin{array}{l}\text { Normal } \\
(31-64 \%)\end{array}$ & 135 & 83.3 & 11 & 61.1 & 7 & 58.3 \\
\hline $\begin{array}{l}\text { Increased } \\
\text { (More than } 64 \%)\end{array}$ & 1 & 0.6 & 0 & 0 & 0 & 0 \\
\hline $\begin{array}{c}\text { Decreased } \\
\text { (Less than 31\%) }\end{array}$ & 26 & 16.0 & 7 & 38.8 & 5 & 41.6 \\
\hline Total & 162 & 100 & 18 & 100 & 12 & 100 \\
\hline $\mathrm{X}^{2}=9.286$ & \multicolumn{2}{|c|}{$P=0.045$} & & .05 & \multicolumn{2}{|c|}{ Significan } \\
\hline
\end{tabular}


Table 3: Comparison the CD4 percentage of HCMV seropositive with seronegative groups.

\begin{tabular}{|c|c|c|c|c|c|c|}
\hline \multirow{4}{*}{$\begin{array}{l}\text { CD4 } \\
\text { Percentage } \\
\text { results }\end{array}$} & \multicolumn{6}{|c|}{ Examined groups } \\
\hline & \multirow{2}{*}{\multicolumn{2}{|c|}{$\begin{array}{l}\text { HCMV Seropositive } \\
\text { pregnant women }\end{array}$}} & \multicolumn{4}{|c|}{ Control groups } \\
\hline & & & \multicolumn{2}{|c|}{$\begin{array}{c}\text { HCMV } \\
\text { (Seronegative pregnant women) }\end{array}$} & \multicolumn{2}{|c|}{$\begin{array}{c}\text { HCMV } \\
\text { (Seronegative non-pregnant } \\
\text { women) } \\
\end{array}$} \\
\hline & No. & $\%$ & No. & $\%$ & No. & $\%$ \\
\hline Normal & 153 & 79.68 & 8 & 100 & 79 & 97.60 \\
\hline Increased & 1 & 0.53 & 0 & $\mathbf{0}$ & 1 & 1.20 \\
\hline Decreased & 38 & 19.79 & $\mathbf{0}$ & $\mathbf{0}$ & 1 & 1.20 \\
\hline Total & 192 & 100 & 8 & 100 & 81 & 100 \\
\hline \multicolumn{7}{|c|}{$X^{2}=18.073$} \\
\hline
\end{tabular}

Table 4: Relation of HCMV antibodies with CRP.

\begin{tabular}{|c|c|c|c|c|c|c|}
\hline \multirow{3}{*}{ CRP results } & \multicolumn{6}{|c|}{ HCMV antibodies } \\
\hline & \multicolumn{2}{|c|}{ HCMV- IgG } & \multicolumn{2}{|c|}{ HCMV-IgM } & \multicolumn{2}{|c|}{ HCMV (IgG \& IgM) } \\
\hline & No. & $\%$ & No. & $\%$ & No. & $\%$ \\
\hline Positive & 12 & 7.40 & 3 & 16.66 & 1 & 8.33 \\
\hline Negative & 150 & 92.60 & 15 & 83.34 & 11 & 91.67 \\
\hline \multirow[t]{2}{*}{ Total } & 162 & 100 & 18 & 100 & 12 & 100 \\
\hline & \multicolumn{4}{|c|}{$\mathrm{X}^{2}=1.818$} & & \\
\hline
\end{tabular}

Table 5: Correlation of HCMV antibodies with CD4 percentage and CRP.

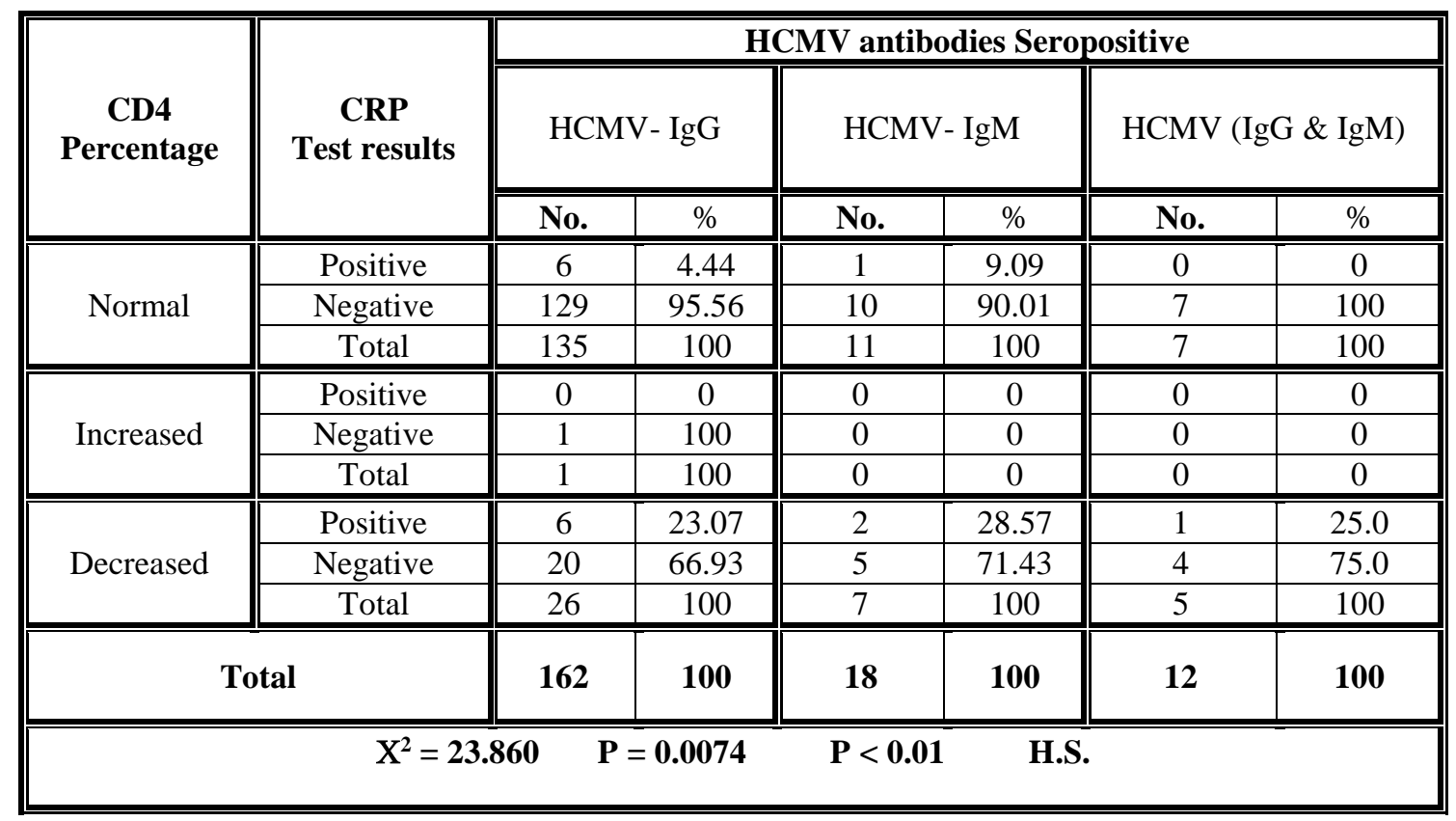




\section{DISCUSSION}

The HCMV remains a major cause of congenital infection and disease during pregnancy around the world1.HCMV seroprevalence across the globe varies substantially both between and within countries [25]. The lower socioeconomic groups have a higher incidence of HCMV exposure and resource-poor countries also have higher seroprevalence levels of HCMV-IgG ranged from $84 \%$ to $100 \%$ [26].

In the presented study indicated the rate of HCMV- IgG seropositive that that past infection among 200 pregnant women was $162(81.0 \%)$. Although the current study recorded the rate of HCMV-IgG seroprevalence closed to world seroprevalence range of HCMV-IgG $40 \%$ to $100 \%$ , and slightly lower than levels of the ranges of poor countries with regardless to different serological tests used in this study, in addition the most previous studies in Iraq and other countries used only ELISA technique for HCMV in pregnant women, these studies showed occasionally the same or close results, where lower than recorded by other study in Iraq (Thi-Qar) revealed $90 \%$, in Egypt $96.0 \%$,in Nigeria $94.8 \%$, in Iran $93.34 \%$ and in Singapore $87.0 \%$, while higher than that recorded in other countries ;in France $46.8 \%$, in the United Kingdom $54.4 \%$ and in Australia 56.9\%. Regarding to the rate of HCMV- IgM that indicate the primary infection in the present study the rates was $18(9.0 \%)$, also this finding was close to world HCMV- IgM prevalence $0-10 \%$, but still higher than recorded; where by others study in Iraq revealed 2.5\%, while in Finland $4 \%$ and in Australia $1.2 \%$ [25-32].

These different rates may be due to differences in hygienic, socioeconomic, and cultural factors, also most of these countries regarded as to developed countries. Many studies from different countries indicated that the seroprevalence of HCMV antibodies among women of childbearing age in developing countries and in populations with low socioeconomic status is generally higher than that in developed countries[33].The variation of results may attributed to the kinetics of anti-HCMVIgM responses during the primary infection which vary greatly among individuals, also this variation may be due to variability of viral accessibility and its circulation rate in the community.

Considering the rate of both HCMV- IgG and HCMV$\operatorname{IgM}$ seropositive at same time in pregnant women that indicate re-infection or sub-acute infection the presented study revealed $12(6.0 \%)$ seropositive among the total 200 examined pregnant women, so this result were close to that recorded ; in Iraq which revealed $6.4 \%$,while in Australia $4.2 \%$, and lower than recorded by other studies as in Iran $(8.0 \%)$, while higher than reported in Turkey $(1.9 \%)$ and in Italy $(0.9 \%)[25-32,34,35]$.This variation in results may be due to follow or ignorance the right rules of health to limit the infection again or re-exposure to infected people or their excretion, which considered as the most important modes of HCMV transmission.

In comparison, the rates of HCMV antibodies among pregnant women and control group (non-pregnant women) the rates were relatively higher in pregnant women with highly significant relation $P<0.01$ as shown in (table 1), this finding may due the immunological and physiological with hormonal imbalance increasing susceptibility of pregnant women to infecting by microorganism especially HCMV.

The HCMV infects the majority of human population in their life time and triggers strong immune responses from all arms of the immune system characterized by a dynamic, life-long interaction that the host immune responses, particularly $\mathrm{T}$-cells, restrain viral replication and prevent the disease. $\mathrm{T}$ lymphocytes is critical for protection from active HCMV infection [36,37].

The current study revealed that the rate of CD4 percentage decreased among HCMV seropositive pregnant women with different rates depending on the antibody type ,so the highest rate of decreased seen within seropositive group for both HCMV-IgM and $\operatorname{IgG}$ at the same time were $41.66 \%$ with significant relation $\mathrm{P}<0.05$ as shown in (table 2), also in comparison the rates with seronegative groups this study revealed highly significant relation $\mathrm{P}<0.01$, which the higher rates of CD4 percentage were within normal rates among most seronegative groups. This finding may due the effect of HCMV to stimulate the immune system and evading by modulation this system through prevent production and differentiation of important immune cells especially $\mathrm{T}$-cells that differentiate to CD4. When the human body is invaded by bacteria or virus, or its immune system is misbalanced, CD4 percentage will fluctuate significantly, thus directly reflecting human body's immune status [17].

The percentages of CD markers are of great importance in the clinical diagnosis, disease progression monitoring and efficacy evaluations of diseases as viral infection including cytomegalovirus. Any alteration in any parameter of the immune system can affect the health of the pregnant woman as well as the outcome of pregnancy. Thus, the immune status of the mother plays an important role in this process [38]. Regarding the effect of these CD markers on some cytokines, ithas been reported that cytokines play an important role in success and failure of pregnancy [39]. Cytokines are immunomodulatory proteins representing a group of proteins and peptides that are used in organisms as signaling compounds allowing communication between the cells. They are particularly important in both innate and adaptive immune responses. Due to their central role in the immune system, cytokines are involved in a variety of immunological, inflammatory and infectious disease [40].

The HCMV is a common viral infection among pregnant women and in addition their effect of pregnancy and the fetus, which may be a cause of systemic inflammation. The interleukin-6 (IL-6) is mainly produced by circulating and peripheral cells and induces the hepatic to synthesis the CRP [41].

The current study indicated that rate of positive results of CRP test among HCMV seropositive pregnant women were ranged from $7.40 \%$ to $16.66 \%$ among all seropositive state, so the highest rate of positive was among HCMV-IgM seropositive group with nonsignificant relation $P>0.05$ as shown in (table 4 ), while in regard to the correlation of CRP with CD4 percentage among HCMV seropositive pregnant women the present study indicated the highest rates of positive CRP ranged from $23.07 \%$ to $28.57 \%$ within decreased CD4 percentage groups with highly significant relation $P<0.01$ as shown in (table 5). These findings may due to the effect of HCMV during the infection induce CRP through systemic 
inflammation and mainly when depressed the rates of peripheral CD4 count.

The CRP expression is assumed to be restricted mainly to the liver where produced under the control of various proinflammatory cytokines including IL-6, so the IL-6 has escorta HCMV replication and could a favor for CRP production in the liver during HCMV-infection and the CRP levels were increased. Therefore, the HCMV infection is strongly associated with high CRP levels as a marker of underlying inflammation in individuals [4144].

Higher CRP concentrations have been associated with lower peripheral CD4 counts and many studies have revealed a significant association between increased CRP concentration and some viral infection, so the clinically elevated CRP concentration was significantly associated with reduced mortality risk of infection [45]. Moreover, the HCMV may mediate inflammatory responses, so the HCMV antibodies up-regulation may increase inflammatory cytokines and elevated levels of CRP [46].

\section{CONCLUSION}

The presented study concluded the rate of HCMV seroprevalence among pregnant women was high and relatively HCMV-IgG higher than HCMV-IgM, so the peripheral CD4 percentage decrease during HCMV infection and the ability of HCMV to act a systemic inflammatory causative to induce CRP production, with highly significant correlation in decreasing the CD4 percentage during HCMV infection in pregnancy.

\section{REFERENCE}

[1] E. U. Umeh, T. O. Onoja, C. U. Aguoru, J. C. Umeh. "Seroprevalence of Cytomegalovirus Antibodies in Pregnant Women", J Infect Dis Ther ,3:5,2015,

[2] M. S. Chee, A. T. Bankier, S. Beck, R. Bohni, C. M. Brown, R. Cerny, T. Horsnell et al." Analysis of the protein-coding content of the sequence of human cytomegalovirus strain AD 169", Curr Top MicrobiolImmunol 154, 125, 1990.

[3] J.D. Smith, E.T. de Harven, "Herpes simplex virus and human cytomegalovirus replication in WI-38 cells. I. Sequence of viral replication" J Virol 12: 919, 1978.

[4] Z. Maingi, A. K. Nyamache."Seroprevalence of Cytomegalo Virus (CMV) among pregnant women in HLkD", Kenya. BMC Res Notes 7: 79,2014.

[5] S. Bonalumi, A. Trapanese. L.Santamaria, D'Emidio, L. Mobili, "Cytomegalovirus infection in pregnancy: review of the literature,"Journal of Prenatal Medicine, 5(1), pp. 1-8,2011.

[6] C. T. Nelson, G. J. Demmler, "Cytomegalovirus infection in the pregnant mother, fetus, and newborn infant," Clinics inPerinatology, 24(1), pp. 151-160, 1997.

[7] G. Enders, A. Daiminger, U. Bader, S. Exler, M. Enders, "Intrauterine transmission and clinical outcome of 248 pregnancies with primary cytomegalovirus infection in relation to gestational age,'Journal of Clinical Virology, 52(3), pp. 244-246, 2011

[8] C. Gardella, Cytomegalovirus in Pregnancy, In The Global Library of Women's Medicine DOI, 2008.

[9] C. T. Nelson, G. D. Demmler, "Cytomegalovirus infection in the pregnant mother, fetus, and newborn infant," ClinPerinatol, 24(1), pp.51-60, 1997.
[10] S. Jackson, G. Mason, G. Okecha, J. Sissons,M. Wills, "Diverse specificities, phenotypes, and antiviral activities of cytomegalovirus-specific CD8+ T cells", J Virol,88, pp.1089410908,2014 .

[11] S. Jackson, G. Sedikides, G. Mason, G. Okecha, M. Wills, "Human cytomegalovirus (HCMV)-specific CD4+ $\mathrm{T}$ cells are poly functional and can respond to HCMV-infecteddendritic cells In Vitro," J Viro, 91, pp.161-168,2017.

[12] P. Griffiths, "CMV as a cofactor enhancing progression of AIDS," J ClinVirol, 35(4), pp. 489-92,2006.

[13] Y. Thoman, L. Rogozinski, Irogoyen O,"Functional analysis of human $\mathrm{T}$ cell subsets defined by monoclonal antibodies" J Immunol,128, pp. 1386-1390, 1983.

[14] N. Hayashi, H. Kimura, T. Morishima, N. Tanaka, T. Tsurumi, K. Kuzushima, "Flow cytometric analysis of cytomegalovirusspecific cell mediatedimmunity in the congenital infection," $J$ Med Virol,71, pp,251-258, 2003.

[15] N. Khan, "The immunological burden of human cytomegalovirus infection," Arch ImmunolTherExp, 55, pp.299-308,2007.

[16] G. Nebbia, F. M. Mattes, C. Smith C, "Polyfunctional cytomegalovirus-specific CD4+ and pp65 CD8+ T cells protect against high-level replication after liver transplantation," Am. J Trans, 8, pp.2590-2599, 2008 .

[17] H. R. Nicolle, W. Elly, G. H. Michiel, "Differential effects of age, cytomegalovirusseropositivity and end-stage renal disease (ESRD) on circulating T lymphocyte subsets," Immu\& Age J. pp.2-10, 2011.

[18] T. W. Du Clos, C. Mold, "C-reactive protein: an activator of innate immunity and a modulator of adaptive immunity," Immunol Res, 30, pp.261-77, 2004.

[19] A. J. Szalai, J. L.VanCott, J. R. McGhee, J. Volanakis,W. H. Benjamin, "Human C-reactive protein is protective against fatal Salmonella entericserovar Typhimurium infection in transgenic mice," Infect Immun, 68, pp.5652- 5656, 2000.

[20[ E. J. Tter Borg, G. Horst, P. C. Limburg, M. H. van Rijswijk, C. G. Kallenberg, "C-reactive protein levels during disease exacerbations and infections in systemic lupus erythematosus: a prospective longitudinal study," J Rheumatol,17, pp.1642$1648,1990$.

[21] J. Zhu, A. A. Quyyumi, J. E. Norman, G. Csako, S. E. Epstein. "Cytomegalovirus in the pathogenesis of atherosclerosis: the role of inflammation as reflected by elevated C-reactive protein levels," J Am CollCardiol, 34, pp.312-319, 1999.

[22] G E. Miller, K. E. Freedland, S. Duntley, R. M. Carney, "Relation of depressive symptoms to C-reactive protein and pathogen burden (cytomegalovirus, herpes simplex virus, Epstein-Barr virus) in patients with earlier acute coronary syndromes," Am J Cardiol, 95, pp. 317-21, 2005 .

[23] M. Terik, T. M. Husain, H. David, D. H. Kim, "C-Reactive protein and Erythrocyte Sedimentation rate in Orthopaedics," The University of Pennsylvania Orthopaedic Journal, 15, pp.13-16, 2002.

[24] R. D. Ramamoorthy, V. Nallasamy, R. Reddy, N. Esther, Y. Maruthappan, "A review of C-reactive protein: A diagnostic indicator in periodontal medicine," Journal of Pharmatical Bioallied Science, 4, pp.422-426, 2012.

[25] A. Ahmad, I Al-Khafaji, I Kawakib, A. Al-Zubaidi "Seroprevalence of Cytomegolovirus Infection Among Aborted Women in ThiQar Governorate," J Thi-QarSci,2 (3), pp.23-25, 2010.

[26] A. Wong, K. H. Tan, C. S. Tee, G. S. Yeo, "Seroprevalence of cytomegalovirus, Toxoplasma, and Parvovirus in pregnancy," Singapore Med J ,41(4), pp151-155, 2000.

[27] A. El-Nawawy, A. T. Soliman, O. Azzouni, "Maternal and neonatal prevalence of toxoplasma and cytomegalovirus (CMV) antibodies and hepatitis-B antigens in an Egyptian rural area," J Trop Pediatr, 42(3), pp.154-157, 1996.

[28] A. Alanen, K. Kahala, T. Vahlberg, P. Koskela, R. Vainionpä, "Seroprevalence, incidence of prenatal infections and reliability of maternal history of varicella zoster virus, cytomegalovirus, herpes simplex virus and parvovirus B19 infection in SouthWestern Finland," BJOG, 112(1), pp.50-56, 2005.

[29] T. S. Saraswathy, A. Az-Ulhusna, R. N. Asshikin RN, S. Suriani, S. Zainah, "'Seroprevalence of cytomegalovirus infection 
in pregnant women and associated role in obstetric complications: a preliminary study," The Southeast Asian J Trop Med and Public Health,42 (2), pp.320-323, 2011.

[30] M. Tabatabaee, D. Tayyebi, "Seroepidemiologic study of human cytomegalovirus in pregnant women in Valiasr Hospital of Kazeroon, Fars, Iran,” J Maternal-Fetal Neo Med, 22, pp.517$521,2009$.

[31] S. C. Munro, B. Hall, R. Whybin, "Diagnosis of and Screening for Cytomegalovirus Infection in Pregnant Women," J Clin Microbiol,43(9), pp.4713-4718, 2005.

[32] A. Karabulut, Y. Polat, M. Turk, Y. Isikbalcl, "Evaluation of rubella, Toxoplasma gondii, and cytomegalovirus seroprevalences among pregnant women in Denizli province," Turk J Med Sci,41(1), pp.159-164, 2011.

[33] S. Ocak, S. Zeteroglu, C. Ozer, K. Dolapcioglu, A. Gungoren, "Seroprevalence of Toxoplasma gondii, rubella and cytomegalovirus among pregnant women in southern Turkey," Scand J Infect Dis,39, pp.231-234, 2007.

[34] G. S. Tamer, D. Dundar, E.Caliskan, "Seroprevalence of Toxoplasma gondii, rubella and cytomegalovirus among pregnant women in western region of Turkey," Clin Invest Med ,32(1), 43-47, 2009

[35] Chakravarty A, Kashyap B, RathiK, "The seroepidemiological study on cytomegalovirus in women of child-bearing age with special reference to pregnancy and maternal-fetal transmission," Indian J Pathol Microbiol,48(4), pp.518-521,2005.

[36] B. Pourgheysari, F. Rahmani, "CD4 immune response to cytomegalovirus (CMV) in healthy carriers and hematological malignancies," ShahreUni Med Sci J, 13(2), pp.83-94,2011.

[37] C. Solano, "Enumeration of cytomegalovirus-specific interferong CD8 and CD4+ T cells early after allogeneic stem cell

[46] L Zhen, "High anti-human cytomegalovirus antibody levels are associated with the progression of essential hypertension and target organ damage in Han Chinese population," PloS one 12.8, e0181440, 2017. transplantation may identify patients at risk of active cytomegalovirus infection", Haematologica, 93(9), pp.14341436,2008 .

[38] E. A. Ophori, N. C. Isibor, "Lymphocyte subpopulations among pregnant women in Agbor, Delta State, Nigeria", Asian Pa J Trop Dis, 8(1), pp.293-296, 2012.

[39] R. Raghupathy, "Th-1 type immunity is incompatible with successful pregnancy”, Immunol Today, 10, pp.478-482, 1997.

[40] K. W. Gagandeep, M. Rupak, K. N. Saraswathy, P. S Manju, "Immuno-Molecular Etiology of Recurrent Pregnancy Loss and the Anthropological Perspective," Int J Hum Genet, 8(1-2), pp. 227-235, 2008

[41] B. Lepiller, A. Quentin, "Increased HCMV seroprevalence in patients with hepatocellular carcinoma." Virology journal 8, pp. 485-491, 2011.

[42] J. Hurlimann, G. J. Thorbecke, G. M. Hochwald "The liver as the site of Creactive protein formation," J Exp Med, 123, pp.365378, 1966.

[43] B. Van de, J. Pablo, "Human cytomegalovirus induces systemic immune activation characterized by a type 1 cytokine signature," The Journal of infectious diseases, 202,5, pp. 690-699, 2010.

[44] G. Savva, M. George, "Cytomegalovirus infection is associated with increased mortality in the older population," Aging cell 12,3, pp. 381-338, 2013.

[45] A. Vishwanath, Q Saif, K. Ruhi, "Role of high-sensitivity Creactive protein measurements in HIV patients," Indian journal of sexually transmitted diseases 37, pp.123-128, 2016. 